\title{
Still fighting in the trenches: 'war discourse' and the memory of the First World War in Britain
}

\section{Introduction}

The hundredth anniversaries of the Great War in Britain will be an opportunity to engage in the meanings and memories of a conflict that is regularly described as 'haunting' contemporary society. Numerous scholars have assessed the ways in which the conflict of 1914-1918 has been kept present within society through media representation since the Armistice (see Bond 2002; Winter 2006). Monuments, memorials, film, television and literature have been assessed for the way in which they shape and inform practices of remembrance (Hanna 2009; Todman 2005; Williams 2009). Indeed, these cultural forms have been regarded as the means by which a current generation, far removed from the war itself and now without the conflict's last living witnesses, can access and interpret the significance of the conflict (Badsey 2009). However, this focus on cultural representation has obscured the manner in which the conflict's influence is still mobilised and brought to mind by individuals, groups and communities within contemporary society (after Wilson 2008a). Through language, metaphor and simile, the war is used as a significant social and political tool (after Lakoff and Johnson 2003). Words, phrases and sayings that emerged during the conflict are still drawn upon almost a hundred years after their origin and constitute an identifiable and critical mode of expression (after Ricœur 2004: 129). By assessing this 'war discourse', the memory and connotations of the conflict within contemporary 
Britain can be examined. Rather than assuming that the 'popular memory' results from a vapid consumption of media, this study reveals through a critical analysis of political, media and public discourse, that the war itself provides a symbolic and potentially dissonant resource for society to assesses current issues (after Fairclough 2001: 12).

\section{The First World War and popular memory in Britain}

The prominence of the memory of the Great War in Britain can be explained by the scale of the nation's war-effort in a conflict that resulted in over 700,000 fatalities (Gregory 2008; Winter 1986). To commemorate the 'glorious dead' in the post-war era, memorials and monuments were constructed across the battlefields as well as the villages, towns and cities of Britain (see King 1998; Goebel 2007). This tangible heritage has been well-studied by scholars, who have examined the remembrance of the war from the Armistice to the present day, highlighting the manner in which these objects structure the performance of memory (see Gregory 1994; Moriarty 1999). Indeed, the solemnity of the memorials of the war has been assessed as an 'invention of tradition', formed as a means to emphasise the 'national sacrifice' and to mask the culpability of authority in the deaths of thousands (see Heffernan 1995). In contrast, commentators have also emphasised the way in which this materiality acted as a significant factor in post-war bereavement, whilst serving contemporary society with a means to remember and reflect (Lloyd 1998; Iles 2006). The physical presence of the memorials, therefore, belies the contested nature of the remembrance of the war in Britain (after Hodgkin and Radstone 2003) 
The media representation of the war is equally contentious and regarded by some historians as the basis of an inaccurate set of 'myths and memories' (Sheffield 2002). It is the poems and memoirs of soldier-poets such as Wilfred Owen (1893-1918) and Siegfried Sassoon (1888-1967) that are considered to have particularly influenced this form of remembrance through their powerful, descriptive work. Owen's (1966: 5558) condemnation of patriotism (Dulce Et Decorum Est), his lament for the dead (Anthem for Doomed Youth), or Sassoon's (1983: 47) pitiable portraits of soldiers suffering at the behest of an incompetent military and political elite (The General or Suicide in the Trenches), are observed to have created a fictional perception of the Great War (see Badsey 2001). Thereby providing a basis for subsequent representations in film, television and fiction (see Korte 2001). Contemporary novels such as The Ghost Road (Barker 1991) or Birdsong (Faulks 1993) demonstrate this continuity as they make reference to desolate battlefields, suffering soldiers and the cruelty of authority in the same fashion as the war poets (Pennell 2012). Historians have lamented the persistence of this literary heritage, regarding it as the product of disillusioned officers rather than the view of the ordinary, loyal infantryman (Taylor 2009: 293-294; Watson 2008: 8).

Therefore, whether through the materiality of memory, the immaterial practices of remembrance or the cultural evocations of memory, the commemoration of the First World War in Britain is highly contested (Heathorn 2005). However, the focus with the commemorative and cultural representations of the war seemingly relies on the idea of a vapid consumption of media within society; that individuals and communities passively accept particular visions of the past. It also assumes that wider social forms of remembrance about the war, expressed through different formats and emerging at 
particular junctures, does not exist within contemporary Britain (after Samuel 1994). The focus on cultural representations has obscured the diverse practices of memory within society (see Connerton 1989; Olick 2007). The Great War is remembered in Britain through a multitude of ways and mobilised by agents to address current concerns (after Wertsch 2002: 5-7). Where this active engagement can be most directly observed is in the way in which the war is still talked about but also talked with (after Waterton and Wilson 2009). Through an examination of the 'war discourse', within the political, media and public spheres, the ways in which the conflict is used and valued within society can be assessed (after Brownlie 2012).

\section{War Discourse}

The war of 1914-1918 has left a significant legacy in the language that is used by communities throughout Britain (see Chasseaud 2006). The vernacular language is littered with the vestiges of the conflict which, far from serving a purely illustrative function, relays information both on how the war is remembered and its contemporary meanings. The creation of this 'war discourse' stems from the history of the conflict, where the recruitment of a 'citizen army' with the exposure of over five million individuals to military service, brought society into a closer relationship with martial terminology (see (Beckett and Simpson 1985). Soldiers would be required to familiarise themselves with the formal and informal terms of the army through their training and service whilst a familiarity with the form and function of military equipment would necessitate knowledge of a range of technical terms and phrases. Soldiers during the 
First World War also continued the established tradition of the British Army incorporating or bastardising words from indigenous languages as a means of expression (see Wilson 2011). Soldiers serving in France and Belgian would have been familiar with what was termed 'British Army French', a fusion of poorly pronounced or borrowed words or phrases, the most common being 'bon' (e.g. 'that's bon') or the well-known expression to communicate unimportance 'San Fairy Ann' (Ça ne fait rien - it means nothing). As the war experience was also communicated to the home front, through soldiers' letters, periods on leave and through the media coverage of the war, the terms and sayings shifted from their military context to a domestic sphere (see Brophy and Partridge 1930).

The continuation of these terms in popular usage enables an identification of a 'war discourse' as this deployment of language achieves more than mere description (after Fairclough 2001). 'War discourse' is defined here to describe the use of terms that emerged from the conflict or reference the conflict that are employed within contemporary society in Britain to address issues beyond the confines of the 1914-1918 (after Hunt 2010: 4). The uses of these phrases or words demonstrate how the Great War is mobilised within current society to achieve particular aims (after Wertsch 2002: 9). Indeed, the 'war discourse' provides a critical context for its users to make direct and indirect allusions between the conflict and modern concerns. This function can be examined by applying Fairclough's $(1995,2001)$ delineation of Critical Discourse Analysis (CDA). This approach recognises that the application of discourse is purposeful and possesses social and political effect; discourse forms a framework which interprets issues for wider society (after Bakhtin 1986: 121). CDA is a critical method of analysing the discourses used in society to understand how this means of 
representation structures experience (Fairclough 2001: 15). This method is based upon the identification of genres, discourses and styles within communication (after Fairclough 2003: 26).

Genres can be defined as a framework for an audience to comprehend discourse. Examples of genres are political speeches, church sermons or manifestoes, essentially where communication possesses a particular quality because of the context of its emergence. However, due to this quality, 'genres' can be the locus of resistance as well as domination. 'Discourses' refer to the manner in which the external environment can be apprehended differently from alternative perspectives. As such, discourses can be used to provide dissonant agendas within society as they enable a different position in relation to events or issues. Examples of discourses would be the representation of the view of the 'everyday man' as a means of critiquing or affirming values. Finally, 'styles' are the ways in which discourse is used to constitute a sense of being and identity, how identification is located through the application and manner of particular discourses. A simple example of this process of identification through discourse is the inclusion of the pronouns 'we' or 'us' within a communication to emphasise a common experience or agenda.

Through this application of CDA, the function of 'war discourse' can be assessed. The potential for such a study is evident; the popular lexicon is saturated with connections to the Great War that induce particular effects. To illustrate, mere reference to the 'Somme', 'Passchendaele', 'Gallipoli' or 'the trenches', possesses an unusual capacity to evoke images of ruined landscapes, piteous soldiers and the senseless brutality of conflict. However, this is the overt form of the 'war discourse' which references the conflict itself. Where the 'war discourse' can be assessed for its implicit 
use and as a means of interpreting the present is in its application as a reference (after Brownlie 2012). The presence of phrases and terms demonstrates the cultural and symbolic value of the Great War in Britain and offers an alternative assessment of its remembrance within wider society. Certainly, meanings and uses do alter over time, but this still constitutes a definite aspect of the 'cultural heritage' of the war (Wilson 2013). A survey of this 'war discourse' reveals the extent to which the conflict can be used to talk about contemporary concerns. As such, this study will focus upon the following terms which have been selected due to their prominence as representative of this process:

- Trench warfare - used by wartime politicians, the military and the wider media to describe the new form of warfare that emerged during 1914-1918 (OED 2002: 262)

- In the trenches - a phrase originating with the conflict and used by soldiers to communicate their proximity to the hostilities (OED 2002: 262)

- War of Attrition - a term used to define the tactics employed by the opposing armies on the field of battle (Ammer 1989: 215)

- Over the top - an expression which described the actions of troops in the trenches engaging the enemy (Ammer 1989: 177)

- No man's land - originating in the fourteenth century, but associated with the contested area on the battlefields (Siefring 1999: 201)

- Shell Shock - used to define a medical condition arising from the treatment of traumatised individuals from the battlefields (after Rivers 1918) 
- Blighty - derived from an Urdu word (vilāyatī) meaning 'foreign' which was corrupted by British soldiers in the nineteenth century to serve as an affectionate moniker for 'Britain'. The term obtained wider usage during the Great War where it described both 'home' and a non-fatal wound (Partridge 1966: 50)

- Sayings - the conflict has provided a number of saying such as 'home by Christmas' or 'lost generation' which are intrinsically linked to the war but have obtained a wider social and cultural currency (see Halifax 2010)

- Soldier Poets -this aspect of the war discourse uses the titles and lines from the work of the war poets which have become current within contemporary society

What marks this discourse as distinctive is that it is employed within contemporary society in Britain not to refer to the conflict but to describe and define current issues and values. Terms such as 'Blighty' or 'no man's land' are brought to bear on present-day circumstances to mobilise ideas and memories of the conflict to pass a critical appraisal on modern concerns. It is through the uses of this 'war discourse' that an assessment of the popular memory of the Great War in Britain can be obtained. Within political, media and public discourse, the references to the war are used not only to activate a particular means of remembering the conflict but to use that memory to frame extant topics (see Schudson 1992: 150). To represent issues through the 'war discourse' is to speak both about the past and the present. To demonstrate this function, a variety of sources, political speeches, religious sermons, newspaper reports and public forums, taken from a range of contexts over the last two decades will be examined within this investigation. This data has been obtained through content searches of media which has focused on the use and context of the terms highlighted above. This media has been selected along the 
framework provided by the particular genres, narratives and styles that are identified within CDA. Through this approach, the 'war discourse' can be regarded as a structuring device within society that remembers and retells the narrative of the war for specific agendas. The array of contexts from which this data is obtained demonstrates the operation of power and resistance through this discourse (after Foucault 1972: 23). The chronological frame of twenty years within which the examples have been selected emphasises the function of the 'war discourse', illustrating how it is not what is talked about which is significant, but how it is talked about with reference to the First World War (after Fairclough 2001: 6).

\section{Militarising language: mobilising the war discourse}

One of the most prominent features of the war discourse is the way in which it employs military terms derived from the conflict to comprehend and comment upon current concerns (after Ammer 1989). This can be acutely observed through the uses of the term 'trench warfare' or the phrase 'in the trenches'. During the conflict, these terms abounded within military life; references to 'the trenches' would possess a powerful connotation as they revealed at once the immediacy of experience, the contradictory associations of danger and security afforded by the trenches and the 'reality' of war (Wilson 2008b: 162). Present-day uses of these terms share a great deal in common with these wartime associations, drawing on this effect to frame contemporary issues. Indeed, references to 'being in the trenches' and 'trench warfare' reveals the way in which the popular memory of the conflict is used within society. For example, to evoke 'trench 
warfare' relies on a particular understanding of its association. This can be observed at all levels within society. Indeed, former Prime Minister Tony Blair (1997: 74) framed the 'old politics' of the Labour Party in this manner during his bid for election in 1997:

\footnotetext{
There was fault on both sides, but the atmosphere of trench warfare which so often existed...was unacceptable.
}

Similarly, an article in the political and current affairs magazine, the New Statesman (Bright 2008: 10), described a more recent encounter from 2009 within the Labour Party in the same manner:

In the trench warfare that passes for Labour politics these days, Gordon Brown and his generals have spent the conference season pounding another set of rivals into the dirt...

This usage is not restricted to one side of the political divide, indeed former Prime Minister John Major (1999: 213) makes reference to 'the trenches' in his memoirs as he describes the bruising encounter within his own Conservative Party in 1992:

At the end of it, the Maastricht Treaty had been ratified after a year of gruesome trench warfare in the Commons, but only by the narrowest and most nerve-shattering of margins.

To evoke 'trench warfare' is, therefore, a means of illustration, but it relies upon a particular understanding of the war as a grinding, conflict of attrition with little respite and slight returns in the way of production or development. The popular memory of the war as a bloody and costly endeavour is comprehended and communicated through this 
reference as mentioning 'trench warfare' ensures an audience understands a present context through the framework of this past trauma (after Edkins 2003: 23). The use of 'trench warfare' in this manner operates as a 'genre' - placing the narrative of the war at the disposal of contemporary audiences. Within the political sector, this phrase intriguingly possesses an apolitical quality; 'trench warfare' carries no specific connotations of blame and responsibility, to describe a situation in this fashion serves only to recall the brutal nature of war. However, to place current events within an understanding of 'the trenches', ensures an engagement within a specific discourse, one which uses the memory of the war to draw attention to deficiencies in present-day society (after Žižek 2002: 272). To place oneself or others in 'the trenches' alludes to a sense of exposure and abandonment in the 'firing line'; this can be witnessed in references within newspaper media:

We are the ones in the trenches - we are the frontline of psychiatric care (Anon 2000: 10).

Private sector businesses are still in the trenches of recession (Anon 2010: 21).

A losing battle in the trenches - Residents have no control over construction work on their doorsteps (Spackman 1994: 12)

What is significant in this use of the war discourse is the tenor given to these issues of healthcare, business and housing through the context of the conflict of 1914-1918. To evoke the view from 'the trenches' carries more than the power of description, it communicates issues of culpability and responsibility for the position faced by individuals. This is especially evident in the reporting of the experience of British 
soldiers in the recent conflicts in Iraq and Afghanistan (after Hoskins and O'Loughlin 2010). Several newspaper reports evoked the memory of the Great War, and specifically the Western Front, in critical pieces which decried the tactics and the progress of these operations. For example, The Scotsman (Cumming 2007: 12) reported in January 2007 of the incredulity of troops occupying trenches in Afghanistan, 'Almost 100 years after WWI, British troops have returned to the trenches'. Similarly, the Mail on Sunday described troop engagements with Taliban forces in Helmand Province in January 2009 with the headline: 'It's back to the trenches, Helmand-style' (Anon 2009: 5). The framing of the Afghanistan campaign in the context of the Great War enables a critical emphasis to emerge. To represent a discourse 'from the trenches' imbues this perspective with significance, it denotes experience, hardship and suffering at the behest of an authority. To place oneself within the 'trenches' in this fashion is to assume the mantle of heroic victim from which a valuable and apparently 'truthful' account can be derived. The frequency in which the 'trenches' are placed within contemporary discourse, implicitly and explicitly referencing the Great War, demonstrates the place of the conflict as a communicable and understandable format in which to convey meaning and value (after Connerton 1989: 10).

This use of military terms from the conflict to frame current issues is also demonstrated in the employment of the phrases 'over the top' and 'war of attrition'. Both of these expressions emerged during the conflict to describe operations on the battlefield but have been subsequently incorporated within a public use to refer to questionable actions and decisions. Within the trade union movement and wider socialist organisations within Britain, denoting a 'war of attrition' with government 
policy or corporations provides an implicit link with the Great War as it characterises a battle between the ordinary individuals and the governing elite:

Local government unions at Southampton City Council have settled into a low-level war of attrition with council bosses after an impressive campaign of creative, rank-and-file-driven industrial action in 2011 failed to prevent the imposition of new contracts (Ward 2012: 11).

... because they are usually unable to mobilise the offensive power of the rank and file, these activists find it hard to act independently of the full-time officials...they have...often been worn down by the endless war of attrition waged by the bosses (Callinicos 2006: 14)

In a similar manner, the employment of the phase 'over the top' at once denotes a censure of behaviour and denunciation of seemingly inept tactics to achieve a pointless result. For example:

So we'll all be going over the top...in some absurd attempt to fulfil Blair's promise to turn round the NHS (National Health Service) by the time of the next election (Hammond 2003).

The wider usage of 'over the top' as a criticism of an infraction of social norms or the common good possesses a means of making implicit links to the events of the Great War. The uses of these terms to draw attention to the conflict demonstrate the qualities of Fairclough's (2003: 26) category of 'discourse'. Militarised sayings and expressions provide a capacity to take alternative perspectives, occasionally dissonant, to make assessments of wider values and attitudes.

It is within the uses of another expression from the battlefields, that of 'no man's land', in which a means of demonstrating a sense of self and identification through 
'styles' can be observed. The 'no man's land' of wartime northern France, Flanders and Gallipoli becomes imposed upon contemporary issues; the former providing meaning and milieu to the latter. This affecting and sentimental frame is used to engage and activate public opinion (after Fairclough 1995: 132). When used to refer to a collective, the term 'no man's land' operates at symbolic level as it denotes a shared experience or suffering. To be in 'no man's land' with others is a mark of solidarity. The usage of the expression in this respect is politically driven as it critiques authority by placing responsibility for the location of individuals or groups in the exposed, dangerous position of 'no man's land. Individuals are 'left' or 'stranded' in 'no man's land' by officials, local government or the national administration. From education, healthcare provision and housing, the neglect of care is highlighted in the expression within local and national media in a variety of contexts:

'It's left me in no man's land, wondering and worrying. Breast cancer survivors are not out of the woods until they are five years clear after the cancer and I'm not even two years down the line (Fleming and Vousden 2009: 14).

Many Plymouth people are trapped in no man's land looking for a home. Do they rent or buy? Can they afford to rent or buy? Due to the lack of suitable accommodation at sensible rents many are forced into buying property they cannot afford (Williams 2008: 10)

These are babies who are born slightly before their due date who need to stay in hospital for just a few days. Mrs Brown believes the parents of such children often find themselves in a "noman's land" (Anon 2006: 15). 
The accusatory nature of describing a predicament as 'no man's land' draws upon the perception of the Great War as an exercise in futility, perpetuated by incompetent or indifferent officials (see Clarke 1961). However, the sense of community and solidarity present in the description of being in 'no man's land' together is a significant aspect of left-wing political sentiment in Britain. Indeed, this usage of the term can be observed in the comments made by the politician George Galloway as he attempts to rally supporters to the cause of rejecting mainstream political parties:

That's why we go over the top into no man's land next week full of hope. And this time we are determined to overrun the enemies' lines (Galloway 2004).

The Scottish Socialist politician John McAllion also mobilises the term to call for cooperation within left-wing politics in Scotland:

We need to get out of our party political trenches and meet somewhere on the political equivalent of no man's land (McAllion 2007).

The ability of the term 'no man's land' to communicate a sense of common identity and belonging is significant. The socialist, Liverpool-based band The Farm (1990) evoked this sentiment in their song, All together now, which encouraged society to forgo selfinterest to meet in 'no man's land'. The capacity of the term to evoke the identity of the 'everyman' experience has also been used to demonstrate agendas beyond left-wing politics. Indeed, the application of the term 'no man's land' in the reporting of British troops involvement in Iraq and Afghanistan, served to intensify and to sympathise with the experience of current members of the armed forces by placing it into the context of 
the victimhood of the soldiers of the Great War. The scale of loss, the prolonged length of the conflict and the public perception of the seemingly futile nature of the Great War ensures that the phrase does more than provide colourful description for reports. Indeed, allusions between the Iraq and Afghanistan campaigns and the First World War were especially common in critical reports of the conflicts fought as part of the 'war on terror':

Iraq is a Bloody No Man's Land. America has Failed to Win the War. But has it Lost it? (Cockburn 2005: 22).

However, in the context of these recent conflicts, the term has been mobilised to support establishment interests, most noticeably in the reporting of tour of duty in Afghanistan by Prince Henry of Wales in 2008. This war service by a member of the British Royal Family was abruptly ended after press speculation led to concerns for safety of the royal and those serving with him. However, the reporting of the Prince's service brought an opportunity to 'place' the royal in the context of 'no man's land', in scenes reminiscent of the Great War. Newspapers recounted the Prince's service in the battlezones of Afghanistan which was re-visioned as the battlefields of 1914-1918.

Manning a powerful machine gun for the first time, the prince fired round after round across cratered No Man's Land, using only distant puffs of smoke as his target (Hickley 2008: 4)

Harry manned the .50 calibre machinegun for the first time, firing across no man's land while a Gurkha filmed on Harry's handheld camera. "This is the first time I've fired a .50 cal," he admitted with a grin. "It's just no man's land. They poke their heads up and that's it (MacIntyre 2008: 4) 
The right-wing, conservative leanings of the papers who drew upon this phrasing provide a means of framing the Prince's experiences within the setting of the Great War. It creates a link to the 'everyman' experience associated with the troops of the 1914-1918 conflict. The service of the grandson of Queen Elizabeth II is thereby rendered into just another 'Tommy in the trenches'; one who shares in the suffering and exhibits the stoicism associated with the troops. In this respect, being 'in no man's land' is a mark of camaraderie with your contemporaries. Therefore, the militarised language of the war discourse affords a means of framing the present within the remembrance of the past.

\section{Sympathising language: using the war discourse}

The capacity of the 'style' of the war discourse to create particular identities and ways of being is certainly evident in the use of the term 'shellshock' within contemporary society. Whilst originally describing a medical condition, to define oneself or others as suffering from 'shell shock' or as being 'shell-shocked' has become a heavily utilised idiom within a variety of fields of discourse within communities and groups in Britain. Despite the proliferation of the term as a vibrant and sensational 'headline-grabber', the expression also operates as part of the 'war discourse' as it contributes to a subtle arrangement of politics and power. To state that another is suffering from 'shell shock' is to place that individual within a framework constructed from the memory of the Great War. This requires a positioning of that individual or group as a 'victim', one who has 
suffered or has undergone a traumatic experience. In the context of the economic downturns or uncertainties, the term has become particularly prevalent in describing the 'casualties' of government cutbacks or company restructuring:

\footnotetext{
Many people who are made redundant often feel shell-shocked as it's the first time they have ever been out of work (Johnson 2009: 14)

The warehouse supervisor, from Penyfan Road, in Llanelli, was left totally shell-shocked on Thursday afternoon after being told the Ministry of Defence was axing its storage depot in Llangennech (Anon 2005: 10)
}

The term in this respect provides a means of demonstrating a 'victim' status, as 'shell shock' is an expression that denotes a state of affliction which has been wrought by forces beyond the control of that sufferer. Issues of responsibility are latent within this usage, as those pained by this condition are granted a status of innocence whilst another bears the accountability for this situation either directly or indirectly through a disregard of their obligations. Whilst 'shell shock' provides a potential source of identification with dissent through this stylistic aspect of the war discourse, 'blighty' offers another means of identification. Although the wartime uses of the term to refer to wounds suffered on the battlefield and requiring relocation to convalesce are no longer pertinent, contemporary usage still relies upon the romantic associations of home and place that are evoked with the term. In its contemporary usage, 'Blighty' is employed as a means of expressing attachment and place and to differentiate 'here' from 'over there'. Such usages refer to Britain's power and prestige but also to idealised visions of 'home'. For example, 'Dear old Blighty's truly world class' (Reece 2009: 22) or 'Why Blighty 
breeds a better class of bounder' (Pelling 2012: 20). In this manner, 'Blighty' assumes a jocular, patriotic reference which enables and promotes a collective identity through a means of common reference. 'Blighty' still possesses a degree of cultural capital. Indeed, the term is used unhesitatingly within a commercial setting for tea shops, antique stores, television programmes and boutiques, all of which provide sentimental, nostalgic products and visions of 'Britain' (after Lowenthal 1985). This usage recalls the lyrics of the popular wartime song 'Take me back to dear old Blighty' (Mills et al., 1917) and evidences a romantic nationalism across society. Within the political sector, the reference enables a conservative, patriotic sentiment to be evoked regardless of the context:

\footnotetext{
...thinking of nice warm beer and sandwiches back in good old blighty (HC Deb 24 April 1996 vol 276, c.358)
}

They have been in Germany, Spain or Portugal, so why should they suddenly have protection when they get back to good old Blighty? (HC Deb 25 March 2003 vol 402, c.196).

What is strikingly discernible in this romantic style is a conservative element that appeals to a narrow, nationalistic sense of 'Britain' (see Low and McArthur 2011). Even critical assessments of national life that reference 'dear old Blighty' do so through a veil of sentimentality that harks back to a 'better time'. Styling oneself or others as occupying a place in 'Blighty' evokes elements which counters the assumption of the 'popular memory' of the Great War as a product of 'left-wing' politics. The war discourse acts as a symbolic resource which can be drawn upon by contemporary audiences to frame current issues within the context of historic events. 
Similarly, identities, perspectives and authority can be challenged or reiterated through the sayings associated with the conflict of 1914-1918. For example, the phrase 'home by Christmas' was associated with the departure of troops to the front lines in August 1914 who were assured by political leaders that the war would be short-lived (Halifax 2010). Although the origins of the phrase have been debated, in modern usage, 'home by Christmas' or 'over by Christmas' has become a phrase framed in context with the war and its unplanned longevity. Its association as part of the 'old lie' told by authorities to soldiers serves to outline contemporary events within this framework. For example, in October 2004, former Prime Minister Tony Blair reassured Parliament that the Black Watch Regiment recently deployed to the 'Triangle of Death' in Iraq would be 'home by Christmas': ' ... the Black Watch will still be back home by Christmas at the end of their six-month period' (HC Deb, 20 October 2004, c883). This statement served to draw direct comparisons with the events of 1914 to 1918 as national newspapers used the title to cast doubt on the Prime Minister's strategy and aims in the war (see Eastham 2004). Peace campaigners, left-leaning intellectuals and opposition politicians all rounded upon the claim that troops would be 'home by Christmas' (Harris 2004). Indeed, the socialist newspaper, the Morning Star reported the story within the frame of understanding derived from the Great War (Bagley 2004):

\footnotetext{
A Stop the War Coalition spokesman recalled that the notorious phrase home by Christmas had been heard before when troops were sent to war. He added: Last time, it presaged a descent into endless slaughter - and that is what Tony Blair is committing the British troops to today.
}

Similarly, the International Marxist Tendency also reported the story with reference to the events of 1914-1918 (Lyon 2004): 
Blair even announced that the Black Watch would be home before Christmas. This is a pledge that may come back to haunt him, as it did British commanders at the beginning of World War 1.

In this manner, the genre of the phrase is mobilised as a frame to comprehend and interpret current events as a means of criticising the actions of present-day authorities (after Wertsch 2002: 26). In a less explicit manner, to speak of the 'lost generation' conjures perceptions of loss, suffering, neglect, responsibility and blame (see Winter 1977). Whilst historically inaccurate, the phrase gained a great deal of cultural currency both during and after the conflict. In a contemporary context, it is a powerful means to view contemporary issues as it eludes to a critique of authority, a denunciation of power and an identification with victimhood. For example, in the context of the recession after 2008 , the myth has been relied upon as a means of stressing the 'victimisation' of a younger generation across Britain as access to resources and employment has been reduced. Indeed, the tag of the 'lost generation' to describe the young, unemployed members of society has become almost universal:

Fears for 'lost generation' in record unemployment (Roden and Barrow 2011: 6)

'Lost generation' as one in five young people is jobless (Prynn and Cecil 2009: 2)

The mobilisation of this particular aspect of the war discourse provides alternative, critical perspectives on the actions of authority.

Perhaps one of the most powerful aspects of the war discourse is the manner in which lines and titles of the work of the war poets are used within the contemporary 
political, media and public arena. The work of Siegfried Sassoon and Wilfred Owen have achieved canonical status within Britain as they are viewed as representing the 'view from the trenches', providing indictments of the waste and brutality of the conflict. What is noticeable within this aspect of the war discourse is the use of the work of these literary figures to pass judgement on the present. For example, the Labour politician Denis MacShane (Member of Parliament, Rotherham) used these evocations of the 'view from the trenches' in May 2010 in an analytical assessment of the military policy during the conflict in Afghanistan:

I think again and again of a poem of Siegfried Sassoon, which I have altered slightly: Goodmorning; good-morning! the General said When we met him last week on our way to the line. Now the soldiers he smiled at are most of 'em dead (HC Deb, 26 May 2010, c174).

Similarly, the work of Sassoon and its critical stance on the Great War, the suffering of soldiers and the vainglorious actions of the army and government, has been used to outline the 'illegal' operations in Iraq:

First World War poet Siegfried Sassoon's family came from Basra. You smug-faced crowds with kindling eye/Who cheer when soldier lads march by/Sneak home and pray you'll never know/The hell where youth and laughter go, wrote Sassoon in Suicide in the Trenches. Words that ring fresh today (Arbuthnot 2007).

The deaths of British combatants in Iraq and Afghanistan are placed within this context to accuse authorities of irresponsibility and stress the 'victimisation' of those serving their country: 
Helmand province is not the Somme, but Wilfred Owen's lament for squandered life (Anthem for Doomed Youth) has seemed, back in the UK, to echo down the years. What candles may be held to speed them all?/Not in the hands of boys but in their eyes/Shall shine the holy glimmers of goodbyes. (Riddell 2009).

This use of the war discourse is placed in a particular context when it is mobilised within particular genres of authority. This is demonstrated in the appearance of lines, verses and phrases from soldier poets such as Owen and Sassoon in memorial or Armistice Day church services. In this manner, Anthem for Doomed Youth or Sassoon's The General serve the purpose of providing illumination and a challenging agenda for a congregation as they are mobilised to outline current concerns. For example, in the Sermon for Remembrance Sunday, preached by The Very Reverend Michael Sadgrove at Durham Cathedral in November 2006, the poem by Owen, 'Anthem for Doomed Youth', was used to evoke a sense of universality during a time when British servicemen and women were fighting in Iraq and Afghanistan:

\footnotetext{
What passing bells for those who die like cattle? Wrote ... soldier-poet Wilfred Owen - not to insult his fellow soldiers whom he loved dearly, but to point out that when slaughter is relentless and indiscriminate, we need to give even more value to each individual, recognise the humanity of each as someone's parent, someone's child, someone's sibling, colleague and friend
} (Sadgrove 2006).

The perspective of the 'view from the trenches' is in this instance a means of establishing other, potentially dissonant standpoints on the present. The war poets are referenced to provide a framework of understanding and to question current issues across British society. In this critical context, 'Anthem for Doomed Youth' forms an 
indictment against a society who may forget the 'lessons' of the past, as the works of Wilfred Owen are used to outline the present using the perspective of the war poet. The Reverend Nicholas Roderick Holtam called upon this framework and a line from Anthem for Doomed Youth during the Remembrance Day Sermon at St. Martin-in-theField, London in 2008:

There is no celebration of death here, just the knowledge of the pain it causes, the grief of those who remember and wait 'and each slow dusk a drawing down of blinds' (Holtam 2008).

This is further demonstrated in the usage of Anthem for Doomed Youth to begin the memorial service at Halifax Minster for the six members of the Yorkshire Regiment, the 3rd Battalion, The Duke of Wellington Regiment, who were killed in Afghanistan in March 2012:

This poem was written by Wilfred Owen, the great First World War poet, and is entitled Anthem for Doomed Youth, a reminder of how young some of the victims of war often turn out to be (Barber 2012).

The use of this genre of influence to provide a critique or rebuke of authority demonstrates the cultural value of the war discourse and its ability to serve agendas in the present. The war discourse can, therefore, be assessed as to how it provides contemporary society within Britain as a means of remembering the Great War to understand the present. In this respect, the memory of the war is not endangered by the passing of time and the deaths of the last few veterans. The Great War is maintained as a symbolic, cultural resource by groups within society. In effect, it is possible for each 
generation to 'return to the trenches' to mobilise the memory of the conflict through the inaction of the 'war discourse'.

\section{Conclusions}

The events in Britain to mark the centenary of the outbreak of the Great War, which include the funding of museums, memorials and a variety of cultural activities to commemorate the 'service and sacrifice' of the nation, are heralded as an appropriate means to understand and remember the conflict (Department for Culture, Media and Sport 2013). This national, state-sanctioned response to the anniversary will be accompanied by a range of television programmes, documentaries and films which will represent all aspects of the conflict to the wider public (BBC 2013). Within these acts of remembrance, scholars have identified a potential for the marking of the centenary of the war to serve as a means of perpetuating the 'myths and memories' of the conflict (Pennell 2012). However, this process also obscures the construction and function of the popular memory of the Great War in Britain. Rather than passively accepting the representations in politics and popular culture, individuals and communities across Britain actively engage in the memory of the war to form new meanings and associations. This cultural memory of the war across Britain is expressed through the employment of a range of words, metaphors and allusions to mobilise the conflict for a range of purposes in the present (after Wertsch 2002).

This 'war discourse' operates as a means of challenging authority and the exercise of power within society. The memory of the conflict is preserved through the 
employment of these phrases and terms as a disastrous, futile waste. This performance is enacted not because of the received values and ideas communicated to society by an array of inaccurate media portrayals. Rather, it is the result of groups, communities and individuals drawing upon the conflict to frame issues in the present. The memory of the war can be identified as operating as a bulwark against the excesses of power within society as the 'war discourse' can be used to cast issues of blame, neglect and a dereliction of responsibility. There does not exist a singular, popular memory of the Great War in Britain, but a means of remembering through an intangible heritage which can be used to discuss issues far removed from the context of 1914-1918. Revisionist historians have sought to dispel the way in which the war is remembered within Britain as inaccurate and sentimental (see Bond 2002). However, as the hundredth anniversaries of the conflict approach, the place of the war as a cultural trauma in Britain can be investigated, not to undermine and challenge the 'myths and memories' of society, but to understand how a war fought at the outset of the twentieth century does not appear to be over.

\section{Bibliography}

Ammer, C (1989) Fighting Words: From War, Rebellion, and Other Combative Capers. New York: Paragon.

Anon (2005) Workers thrown into turmoil as depot earmarked for closure. Evening 
Post, 23 July, 10.

Anon (2006) Helping babies born in a 'no-man's land'. Lincolnshire Echo, 12 June, 15

Arbuthnot, F (2007) The prince goes to Iraq. Morning Star. Available at:

http://www.morningstaronline.co.uk/news/content/view/full/42348 (accessed on 23 July 2007]).

Badsey, S (2001) Blackadder Goes Forth and the "two Western Fronts" debate. In:

Roberts G and Taylor P (eds) The Historian, Television and Television History.

Luton: University of Luton Press, pp.113-125.

Badsey. S (2009) The British Army in battle and its image 1914-1918. London:

Continuum.

Bagley, R (2004) Black Watch 'back for Christmas'. Morning Star. Available at: http://www.morningstaronline.co.uk/index.php/news /content/view/full /4511 (accessed 2 December 2011).

Bakhtin, M (1986) Speech genres and other late essays. Austin: University of Texas Press.

BBC, (2013) The BBC announces its four-year World War One centenary season. Available at: http://www.bbc.co.uk/mediacentre/latestnews/2013/world-warone-centenary.html (accessed October 16 2013).

Beckett, I and Simpson, K (eds) (1985) A Nation in Arms: a social study of the British Army in the First World War, Manchester: Manchester University Press

Barber, H (2012) Remembrance Service for the Yorkshire Regiment, Halifax Minster. Available at: http://www.halifaxminster.org.uk/index. php/sermons/134-serviceof-remembrance (accessed 22 June 2012).

Barker, P (1991) Regeneration. London: Penguin. 
Blair, T (1997) New Britain: my vision of a young country. London: Westview Press.

Bond, B (2002) The Unquiet Western Front. Cambridge: Cambridge.

Bright, M (2008) No credible alternative. New Statesman, 2 October, 10.

Brownlie, S (2012) Does memory of the distant past matter? Remediating the Norman Conquest. Memory Studies 5(4): 360-377.

Brophy, J and Partridge, E (1930) Songs and Slang of the British Soldier: 1914-1918. London: Andre Deutsch.

Callinicos, A (2006) The politics of the new rank and file. Socialist Worker, 25 March, 14.

Chasseaud, P (2006) Rat's Alley: Trench Names of the Western Front. Stroud: The History Press.

Clarke, A (1961) The Donkeys. London: Hutchison.

Cockburn, P (2005) Iraq is a bloody no man's land. America has failed to win the war. But has it lost it? The Independent, 15 May, 22.

Connerton, P (1989) How Societies Remember. Cambridge: Cambridge University Press.

Cumming, J (2007) Almost 100 years after WWI, British troops have returned to the trenches. The Scotsman, 20 January, 12.

Department for Culture, Media and Sport (2013). Marking relevant national events and ceremonies. Available at: https://www.gov.uk/government/policies/markingrelevant-national-events-and-ceremonies (accessed 13 March 2013).

Eastham, P (2004) Blair's Home by Christmas Pledge. Daily Mail. 21 October, 18.

Edkins, J (2003) Trauma and the Memory of Politics. Cambridge: Cambridge University Press. 
Fairclough, N (1995) Critical discourse analysis: The critical study of language. London: Longman.

Fairclough, N (2001) Language and Power. London: Longman

Fairclough, N (2003) Analysing Discourse: textual analysis for social research. New York and London: Routledge

Faulks, S. (1993) Birdsong. London: Vintage.

Fleming, M and Vousden, P (2009) The Forgotten Cancer Victims. Daily Mail, 31 October, 14.

Foucault, M. (1972) Archaeology of Knowledge. London: Tavistock.

Fussell, P (1975) The Great War and Modern Memory. Oxford: Oxford University Press.

Galloway, G (2004) Mea culpa, that's what we want. The Guardian, 2 June, 23.

Goebal, S (2007) The Great War and Medieval Memory: War, Remembrance and Medievalism in Britain and Germany, 1914-1940. Cambridge: Cambridge University Press.

Gregory, A (1994) The Silence of Memory: Armistice Day, 1919-1946. Oxford: Berg. Gregory, A (2008) The Last Great War: British society and the First World War. Cambridge: Cambridge University Press.

HC Deb (1996) House of Commons Debate: The British Film Industry. 24 April, Vol 276, c.358.

HC Deb (2003) House of Commons Debate: Extradition Bill. 25 March, Vol 402, c.196.

HC Deb (2004) House of Commons Debate: Prime Minister's Questions. 20 October, c. 883

HC Deb (2010) House of Commons Debate: Foreign Affairs and Defence. 26 May, 
Halifax, S (2010) Over by Christmas: British popular opinion and the short war in 1914. First World War Studies 1(2), pp.103-121.

Hammond, P (2003) Tin hats on everyone - we're going over the top. Guidelines in Practice 6(7). Available at: http://www.eguidelines.co.uk leguidelinesmain/gip/out_of_hours/ hammond_july03.htm (accessed: 14 July 2012).

Hanna, E. (2009) The Great War on the Small Screen: Representing the Great War in Contemporary Britain. Edinburgh: Edinburgh University Press.

Harris, G (2004) Blair is putting our boys' lives in jeopardy. The Times, 22 October, 31. Heathorn, S (2005) The Mnemonic Turn in the Cultural Historiography of Britain's Great War. The Historical Journal 48(4), pp.1103-1124.

Heffernan. M (1995) For Ever England: the Western Front and the politics of remembrance in Britain. Ecumene 2(3), pp.293-323.

Hickley, M (2008) From his bunker on the edge of no man's land, Harry opens fire on the Taliban. Daily Mail, 29 February, 4

Hodgkin, K and Radstone, S (2003) Introduction: Contested Pasts, in K. Hodgkin and S. Radstone (eds) Contested Pasts: The Politics of Memory. London: Routledge, pp. $1-21$

Holtam, N R (2008) Remembrance Sunday. Available at: http://www. smitf.org/uploadpdfs/sermon/November\%209\%2008\%20RC.pdf (accessed 13 November 2011).

Hoskins, A and O'Loughlin, B (2010) War and Media: the emergence of diffused war. Cambridge: Polity Press. 
Hunt, N (2010) Memory, War and Trauma. Cambridge: Cambridge University Press. Iles, J (2006) Recalling the Ghosts ofWar: Performing Tourism on the Battlefields of the Western Front. Text and Performance Quarterly, 26(2): pp.162-180.

Johnson, R (2009) Response to redundancy is getting folk back into jobs. Derby Evening Telegraph, 6 August, 14

King, A (1998) Memorials of the Great War in Britain: The Symbolism and Politics of Remembrance. Oxford: Berg.

Korte, B (2001) The Grandfathers' War: RE-imagining World War One in British Novels and Films of the 1990s, in D. Cartmell, I.Q. Hunter, and I. Whelhan (eds) Retrovisions: Reinventing the past in film and fiction. London and Sterling: Pluto Press, pp.120-131.

Lakoff, G and Johnsen, M (2003) Metaphors We Live By. Chicago: The University of Chicago Press

Lloyd, D (1998) Battlefield Tourism: Pilgrimage and the Commemoration of the Great War in Britain, Australia and Canada, 1919-1939. Oxford: Berg.

Lowe, S and McArthur, A (2011) Blighty: The Quest for Britishness, Britain, Britons, Britishness and the British. London: Little Brown.

Lowenthal, D (1985) The Past is a Foreign Country. Cambridge: Cambridge University Press.

Lyon, R (2004) Black Watch Home By Christmas. International Marxist Tendency. Available at: http://www.marxist.com/iraq-black-watch261104.htm (accessed 13 December 2011).

MacIntyre, B (2008) For ten weeks they kept the secret of Widow Six Seven, The Times, 29 February, 4. 
McAllion, J (2007) Shattered Scottish left. Morning Star. Available at:

http://www.morningstaronline.co.uk/news/content/view/full/50970 (accessed 28 September 2011).

Major, J (2000) John Major: the autobiography. London: Harper Collins.

Mills, A, Godfrey, F and Scott, B (1916) Take Me Back To Dear Old Blighty. Star Music.

Moriarty, C (1999) The Material Culture of Great War Remembrance. Journal of Contemporary History 34(4), pp.653-662.

Murdock, B (1990) Fighting Songs and Warring Words: Popular Lyrics of Two World Wars. London: Routledge.

OED (2002) Oxford English Dictionary. Oxford: Oxford University Press.

Olick, J (2007) The Politics of Regret: On Collective Memory and Historical Responsibility. London: Routledge.

Owen, W (1965) The Collected Poems of Wilfred Owen. Chatto and Windus: New York.

Partridge, E (1966) Origins: a short etymological dictionary of modern English. London: Kegan Paul.

Pelling, R (2012) Why Blighty breeds a better class of bounder. Daily Telegraph, 28 February, 20.

Pennell, C (2012) Popular History and Myth-Making: The Role and Responsibility of First World War Historians in the Centenary Commemorations, 2014-2018. Historically Speaking 13(5), pp.11-14.

Prynn, J and Cecil, N (2009) Lost generation as one in five young people is jobless. Evening Standard, 16 September, 2. 
Reece, D (2009) Dear old Blighty's truly world class. Daily Telegraph, 8 October, 22. Ricœur, P (2004) Memory, History, Forgetting. Chicago: University of Chicago Press. Riddell, M (2009) Our troops are giving their lives to safeguard a rigged election. Daily Telegraph, 13 July. Available at: http://www.telegraph.co.uk/comment/ columnists/maryriddell/5819915/Afghanistan-Our-troops-are-giving-their-livesto-safeguard-a-rigged-election.html (accessed 22 July 2009).

Rivers, W H (1918) The Repression of War Experience. Proceedings of the Royal Society of Medicine 11, pp.1-20.

Roden, A and Barrow, B (2011) Fears for 'lost generation' in record unemployment. Daily Mail, 17 November, 6.

Sadgrove, M (2006) Sermon: On Remembrance Sunday, Durham Cathedral. Available at: http://www.durhamcathedral.co.uk/schedule /sermons/100 (accessed 12 July 2009).

Samuel, R (1994) Theatres of Memory. London: Verso.

Sassoon, S (1983) The War Poems. London: Faber.

Schudson, M (1992) Watergate in American Memory. New York: Basic Books.

Sheffield, G (2002) Forgotten Victory, The First World War-Myths and Realities. London: Review.

Siefring, J (ed) (2005) The Oxford Dictionary of Idioms. Oxford: Oxford University Press.

Taylor, D (2009) From Fighting the War to Writing the War: From Glory to Guilt? Contemporary British History 23(3), pp.293-313.

The Farm (1990) All together now. Sony Records.

Todman, D (2005) The Great War: Myth and Memory. London: Hambledon. 
War Office (1914) Infantry Training. London: HMSO, Harrison and Sons.

Ward, S (2012) War of attrition in Southampton. Solidarity, 28 March, 11.

Waterton, E and Wilson, R (2009) 'Talking the talk: responses to the bicentenary of the abolition of the slave trade in government documents, media responses and public forums. Discourse and Society 20(2), pp.381-399.

Watson, A (2008) Enduring the Great War: Combat, Morale and Collapse in the German and British Armies, 1914-1918. Cambridge: Cambridge University Press.

Wertsch, J (2002) Voices of Collective Remembering. Cambridge: Cambridge University Press.

Williams, D (2009) Media, Memory, and the First World War. Montreal: McGillQueen's University Press.

Williams, T (2008) City we can't afford to live in. Plymouth Evening Herald, 6 November, 2008, 10.

Wilson, R (2008a) The Trenches in British Popular Memory. InterCulture 5(2), pp.109118.

Wilson, R (2008b) Strange Hells: a new agenda on the Western Front. Historical Research, 81(211), pp.150-166.

Wilson, R (2011) 'Tommifying the Western Front', Historical Geography 37(3), pp.338-347.

Wilson, R (2013) Cultural Heritage of the Great War in Britain. Aldershot: Ashgate.

Winter, J M (1977) Britain's 'Lost Generation' of the First World War. Population Studies, 31(3), pp.449-466.

Winter, J M (1986) The Great War and the British People. London: Macmillan. 
Winter, J (2006) Remembering War: The Great War and Historical Memory in the 20th Century. New Haven: Yale University Press.

Žižek, S (2002) For They Know Not What They Do: Enjoyment As a Political Factor. London: Verso.

\section{Author}

RJ Wilson is Senior Lecturer in Modern History and Public Heritage at the University of Chichester. He has written on the experience, representation and memory of the First World War in Britain and the United States. His wider research focuses on issues of museum, media and heritage representations in the modern era. 